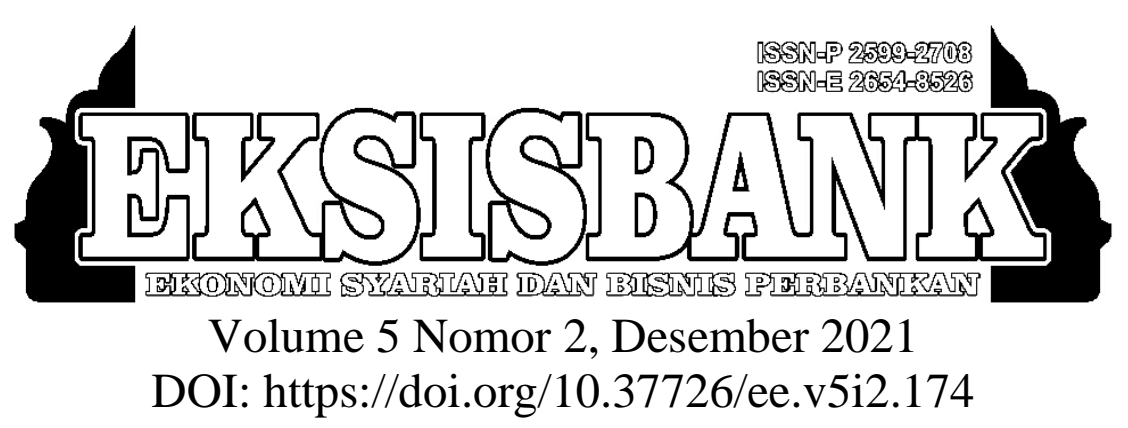

\title{
Pengaruh Tingkat Inflasi Dan Pendapatan Usaha Pegadaian Terhadap Pembiayaan Rahn Pada Pegadaian Syariah Tahun 2011-2020
}

\author{
Siti Aisah ${ }^{1}$, Putri Anjelli ${ }^{2}$, R. Deden Adhianto ${ }^{3}$ \\ ${ }^{1,2,3}$ Politeknik Piksi Ganesha Bandung \\ Jl. Jend. Gatot Subroto No. 301 Bandung 40274 Indonesia \\ ${ }^{1}$ sitiaisyahh310@gmail.com \\ 2panjelli30@gmail.com \\ 3adhiantogd@yahoo.com
}

\begin{abstract}
ABSTRAK
Dalam memutuskan pemberian pembiayaan rahn dipengaruhi oleh berbagai macam kondisi, terutama kondisi internal dan eksternal. Adapun yang termasuk dari faktor atau kondisi internal tersebut yaitu perkembangan pendapatan usaha pegadaian. Untuk sementara itu, kondisi atau faktor eksternal dapat dilihat dari kondisi keuangan yang terjadi di Indonesia, misalnya tingkat inflasi. Penelitian ini bertujuan untuk mengetahui pengaruh tingkat inflasi dan pendapatan usaha terhadap pembiayaan rahn pada perusahaan Pegadaian Syariah di Indonesia secara parsial dan secara simultan. Penelitian ini dilakukan pada lembaga keuangan non-bank yaitu PT.Pegadaian yang berfokuskan pada segmentasi syari'ahnya. Jenis penelitian menggunakan metode deskriptif kuantitatif dengan bersifat asosiatif. Data sekunder yang digunakan pada penelitian ini menggunakan teknik pengumpulan data studi dokumentasi. Penelitian ini menerapkan metode analisis data regresi linear berganda. Berdasarkan hasil analisis data dan pembahasan pada penelitian ini menyatakan bahwa hasil nilai thitung pertama sebesar $-0,030$, artinya $t_{\text {tabel }}$ lebih besar dari thitung $(2,365>-0,030)$ serta sig.0,977 $>0,05$. Dari hasil tersebut inflasi mempunyai pengaruh negatif dan inflasi tidak berpengaruh secara signifikan terhadap pembiayaan rahn secara parsial. Kedua, hasil nilai thitung pada variabel pendapatan usaha menghasilkan $t_{\text {hitung }}$ sebesar 7,141 artinya $t_{\text {hitung }}$ lebih besar dari $t_{\text {tabel }}(7,141>2,365)$ serta nilai signifikan $0,000<0,05$. Dari hasil tersebut berarti pendapatan usaha memiliki pengaruh positif dan pendapatan pegadaian berpengaruh secara signifikan terhadap pembiayaan Rahn secara parsial. Hasil pengujian secara simultan (Uji f) diperoleh hasil nilai $\mathrm{f}_{\text {tabel }}$ sebesar 4,46 karena nilai $\mathrm{f}_{\text {hitung }} 38.698$ lebih besar dari nilai $\mathrm{f}_{\text {tabel }}$ dan nilai signifikansi sebesar 0,000 jauh lebih kecil dari 0,05. Maka dapat disimpulkan bahwa variabel inflasi dan pendapatan pegadaian secara bersamaan berpengaruh terhadap variabel pembiayaan rahn pada Pegadaian Syariah
\end{abstract}

EKSISBANK (Ekonomi Syariah dan Bisnis Perbankan), Volume 5, Nomor 2, Desember 2021 http://journal.sties-purwakarta.ac.id/index.php/EKSISBANK/ 
Indonesia. Serta hubungan antara variabel bebas terhadap variabel terikat dalam penelitian ini sebesar 0,893 atau $89,3 \%$ sedangkan $10,7 \%$ nya dijelaskan oleh faktor lainnya yang tidak dipaparkan dalam penelitian ini.

Kata kunci - Tingkat Inflasi, Pendapatan Usaha, Pembiayan Rahn, Pegadaian Syariah

\begin{abstract}
In deciding the provision of rahn financing, it is influenced by various conditions, especially internal and external conditions. These internal factors or conditions include the development of pawnshop business income. Meanwhile, external conditions or factors can be seen from the financial conditions that occur in Indonesia, for example the inflation rate. This study aims to determine the effect of inflation rate and operating income on rahn financing at Islamic pawnshops in Indonesia partially and simultaneously. This research was conducted at a nonbank financial institution, namely PT. Pawnshops that focus on sharia segmentation. This type of research uses a quantitative descriptive method that is associative. The secondary data used in this study used a documentation study data collection technique. This research uses multiple linear regression data analysis method. Based on the results of the analysis and discussion of the data in this study, it is stated that the first tcount is -0.030 , meaning that ttable is greater than tcount $(2.365>-0.030)$ and sig.0.977 $>0.05$. From these results, inflation has a negative effect and inflation does not have a significant effect on the financing of rahn partially. Second, the results of the tcount value on the operating income variable produce a tcount of 7.141, meaning that tcount is greater than ttable $(7.141>2.365)$ and a significant value of $0.000<$ 0.05. From these results, it means that operating income has a positive effect and pawnshop income has a significant effect on Rahn's financing partially. The results of the simultaneous test (f test) obtained a ftable value of 4.46 because the fcount value of 38,698 is greater than the ftable value and the significance value of 0.000 is much smaller than 0.05 . So it can be concluded that the inflation variable and Pawnshop income simultaneously affect the rahn financing variable at the Indonesian Sharia Pawnshop. And the relationship between the independent variable and the dependent variable in this study was 0.893 or $89.3 \%$, while $10.7 \%$ was explained by other factors not presented in this study.
\end{abstract}

Keywords - Inflation Rate, Operating Income, Rahn Financing, Pegadaian Sharia

\section{PENDAHULUAN}

Kebutuhan ekonomi adalah hal yang tidak bisa dihindari oleh sebagian masyarakat, baik kebutuhan untuk modal usaha, kebutuhan darurat, ataupun kebutuhan sehari-hari, salah satu solusi tercepat untuk menutupi kebutuhan ekonomi tersebut ialah dengan memanfaatkan jasa kredit pada sektor perbankan atau lembaga keuangan non bank. Meningkatnya permintaan dana tunai oleh masyarakat dapat meningkatkan penyaluran kredit oleh perbankan dari waktu ke waktu.
Namun, Meningkatnya kredit perbankan tidak dapat di rasakan oleh masyarakat menengah ke bawah, karena Sulitnya masyarakat dalam mengajukan permohonan pinjaman dan prosedurnya yang lama. Karena sulitnya proses dan syarat yang harus dipenuhi membuat masyarakat menengah kebawah berinisiatif dalam mencari dana yang tidak memiliki syarat yang rumit dan prosesnya lebih cepat (Saputri \& Dewi, 2020).

Kemudian untuk mengatasi permasalahan kredit tersebut salah satunya adalah dengan mengajukan kredit pada lembaga keuangan bukan bank maupun pada pihak perorangan.

EKSISBANK (Ekonomi Syariah dan Bisnis Perbankan), Volume 5, Nomor 2, Desember 2021 
Meningkatnya jumlah kredit oleh masyarakat memberi peluang bagi PT Pegadaian sebagai alternatif untuk menyalurkan kredit pada masyarakat golongan menengah ke bawah yang kurang mendapatkan fasilitas kredit dari perbankan.

PT Pegadaian memiliki visi untuk membantu masyarakat dibidang keuangan. Pegadaian adalah suatu lembaga keuangan non perbankan yang memberikan jasa kredit kepada masyarakat, dimana jasa Pegadaian ini berorientasi pada jaminan. Untuk mengatasi agar masyarakat yang membutuhkan uang tidak jatuh ke tangan para pelepas uang atau tukang ijon atau tukang rentenir yang bunganya relatif tinggi, maka PT Pegadaian menyediakan pinjaman uang dengan jaminan barang-barang berharga. (Aziz, 2013)

Pegadaian merupakan bagian penting dari kegiatan dan sistem perekonomian yang dibutuhkan di negara-negara modern, termasuk Indonesia. Perkembangan produk berbasis syariah semakin marak di Indonesia, termasuk produk yang dihasilkan oleh PT. Pegadaian (Persero) (Rosa et al., 2017).

Salah satu itemnya adalah sistem gadai rahn dengan aturan syariah yang diberikan kepada semua asosiasi masyarakat, baik untuk kebutuhan konsumtif maupun kebutuhan produktif. Menurut (Sulaeman, 2015). Secara garis besar, Rahn menyimpan suatu barang untuk ditahan atau dijadikan sebagai jaminan atau pegangan dalam hal apabila salah satu peminjam tidak dapat mengembalikan kredit dalam waktu yang telah disepakati dan juga selanjutnya sebagai pengikat kepercayaan antara keduanya, agar tidak menimbulkan perbuatan fraud (curang) oleh si peminjam kepada si pemberi pinjaman.

Pegadaian juga sebuah lembaga keuangan yang bertugas untuk membantu meningkatkan kesejahteraan rakyat kecil guna mencegah ijon, renternir dan pinjaman tidak wajar lainnya. Selain itu, pegadaian juga berperan untuk mendukung program pemerintah di bidang ekonomi dan pembangunan nasional.

Berikut adalah perkembangan tingkat inflasi, pendapatan usaha dan pembiayaan (Rahn) Pegadaian Syariah di Indonesia pada Tahun 2011-2020

\section{Tabel 1.1}

Perkembangan Inflasi, Pendapatan Pegadaian dan Pembiayaan Rahn

\begin{tabular}{cccc}
\hline Tahun & $\begin{array}{c}\text { Inflasi } \\
(\%)\end{array}$ & $\begin{array}{c}\text { Pendapatan } \\
(\mathbf{R p})\end{array}$ & $\begin{array}{c}\text { Pembiayaan } \\
\text { Rahn }(\mathbf{R p )})\end{array}$ \\
\hline 2011 & 3,79 & 6.600 .927 & 7.822 .599 \\
\hline 2012 & 4,3 & 7.724 .567 & 11.122 .405 \\
\hline 2013 & 8,38 & 7.864 .767 & 11.535 .454 \\
\hline 2014 & 8,36 & 7.800 .894 & 11.722 .736 \\
\hline 2015 & 3,35 & 8.897 .166 & 13.077 .842 \\
\hline 2016 & 3,02 & 9.708 .058 & 14.096 .938 \\
\hline 2017 & 3,61 & 10.522 .797 & 14.949 .915 \\
\hline 2018 & 3,13 & 11.464 .462 & 16.319 .497 \\
\hline 2019 & 2,72 & 17.693 .653 & 18.897 .575 \\
\hline 2020 & 1,68 & 21.964 .403 & 23.006 .855 \\
\hline
\end{tabular}

(Sumber: Badan Pusat Statistika dan Laporan Tahunan Pegadaian, 2021)

Diagram 1.1

Perkembangan Tingkat Inflasi di Indonesia pada tahun 2011-2020

\section{Inflasi}

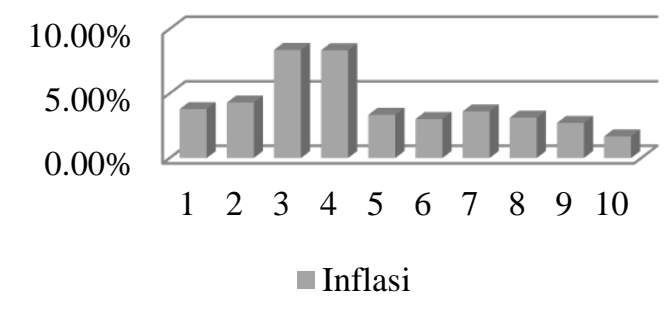

(Sumber: diolah penulis, 2021)

Diagram 1.2

Perkembangan Pendapatan usaha Pegadaian pada tahun 2011-2020 


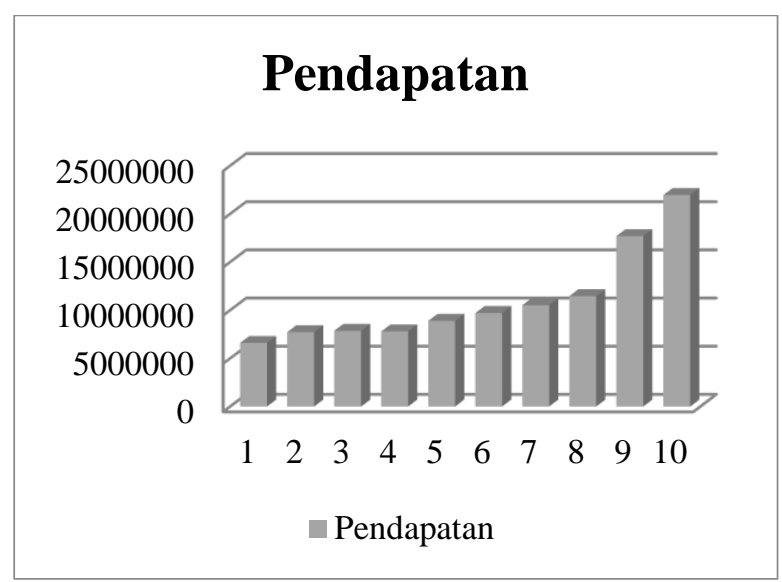

(Sumber: diolah penulis, 2021)

Diagram 1.3

Perkembangan Pembiyaan rahn Pegadaian pada tahun 2011-2020

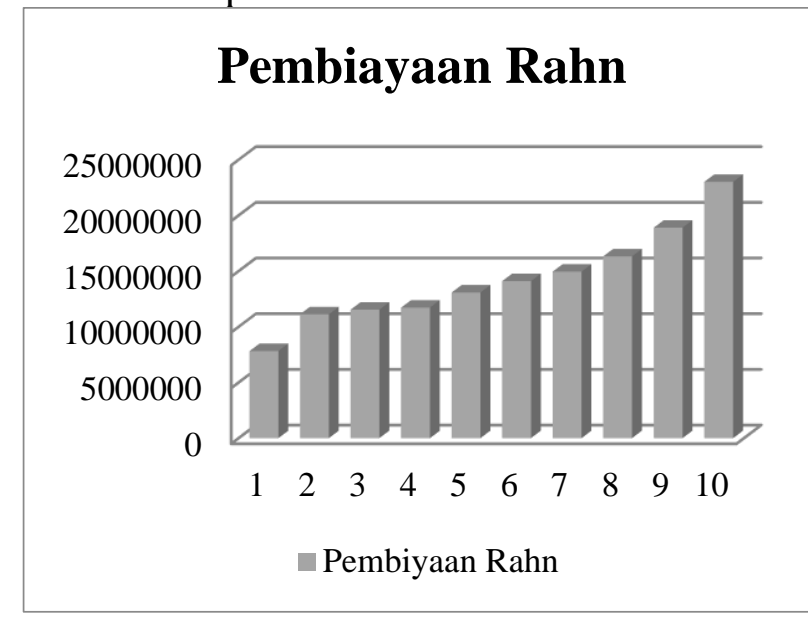

(Sumber: diolah penulis, 2021)

Dalam memutuskan pemberian kredit gadai, Pegadaian Syariah sebagai lembaga pembiayaan gadai dipengaruhi oleh berbagai macam kondisi, terutama kondisi internal dan eksternal. Faktor internal ini dapat dilihat dari bagaimana perusahaan pegadaian dapat mengelola penyaluran kreditnya dengan baik dengan prinsip 5C (capital, character, collateral, capacity, and condition of economy) (Rubianti, 2017).

Adapun yang termasuk dari faktor atau kondisi internal tersebut yaitu perkembangan pendapatan usaha pegadaian. Pendapatan usaha pegadaian sebagai faktor internal mempengaruhi dalam pemberian kredit. Karena semakin banyak kredit yang dikeluarkan, semakin banyak pendapatan yang akan diperoleh perusahaan.

Pendapatan operasional adalah pendapatan yang diperoleh pegadaian dari pengalihan penggunaan (manfaat) suatu barang atau jasa dalam jangka waktu tertentu melalui pembayaran sewa atau upah tanpa diikuti dengan perpindahan kepemilikan barang itu sendiri.

Untuk sementara itu, kondisi atau faktor di luar perusahaan dapat dilihat dari kondisi keuangan yang terjadi di Indonesia, misalnya tingkat inflasi (Aziz, 2013). Karena kondisi atau faktor eksternal tersebut dapat dijadikan semacam perspektif oleh pegadaian dalam memberikan pengembangan aset kredit agar lebih selektif dalam membantu individu yang membutuhkan uang tunai secara cepat dan tepat.

Keadaan tersebut tentunya menjadi hal-hal yang perlu dipertimbangkan oleh PT pegadaian dalam pengambilan keputusan penyaluran pembiayaan terutama pada gadai (Rahn). Berdasarkan dengan permasalahan yang telah diuraikan tersebut. Adapun tujuan dalam penelitian ini yaitu: untuk mengetahui seberapa besar pengaruh tingkat Inflasi dan Pendapatan usaha Pegadaian terhadap Pembiayaan Rahn pada Pegadaian Syariah Indonesia secara parsial pada Tahun 20112020, dan untuk mengetahui seberapa besar pengaruh tingkat Inflasi dan Pendapatan usaha Pegadaian terhadap Pembiayaan Rahn pada Pegadaian Syariah Indonesia secara simultan pada Tahun 2011-2020.

\section{TINJAUAN PUSTAKA}

A. Kajian Teori

Pada artikel ini penulis menggunakan beberapa teori yaitu mengenai Inflasi, Pendapatan dan Rann.

\section{Inflasi}

Dalam pengertian makroekonomi, inflasi dicirikan sebagai kenaikan harga barang dan 
jasa secara umum dan berkelanjutan. Seperti yang dikemukakan Suseno dan Astiyah, dalam konteks ini ada dua gagasan penting yang menjadi kunci dalam memahami inflasi, khususnya kenaikan biaya yang meluas dan tidak henti-hentinya. Hanya kenaikan harga yang terjadi secara umum yang bisa disebut inflasi. Kenaikan harga suatu barang tertentu yang terjadi karena adanya komponen sesekali, misalnya menjelang acara penting atau karena gangguan stok yang singkat dan tidak berdampak lebih lanjut, tidak disebut inflasi (Mankiw, 2018).

Taqyuddin Ahmad Ibn Al-Maqrizi mengungkapkan bahwa pembengkakan inflasi terjadi ketika biaya keseluruhan meningkat tanpa henti. Pada waktu itu, pasokan produk dan jasa mengalami kelangkaan, sementara pembeli harus mengeluarkan lebih banyak uang untuk jumlah jasa dan produk yang sama (Yuniarti, 2016).

Menurut (Aziz, 2013) fluktuasi harga produk dan jasa biasa terjadi dalam kehidupan kita sehari-hari. Misalnya, kenaikan tarif penginapan dan tarif kendaraan udara pada akhir pekan atau musim khusus. Peningkatan ini disebabkan oleh meningkatnya minat pada administrasi transportasi dan penginapan. Di lain kesempatan, kita mengalami kenaikan harga beras karena hasil panen yang mengecewakan atau penurunan harga beras karena panen yang melimpah. Varian biaya, khususnya kenaikan harga pokok barang, yang terjadi karena perubahan permintaan dan penawaran yang bersifat sementara, umumnya tidak mempengaruhi inflasi.

Inflasi menyebabkan dolar pada waktu yang berbeda memiliki nilai riil yang berbeda, melakukan komputasi laba perusahaan selisih antara pendapatan dan biaya. Akan menjadi rumit dalam perekonomian yang memiliki inflasi. Oleh karena itu, dalam beberapa hal, inflasi membuat onvestir menjadi kurang mampu dalam memilah antara perusahaan yang berkembang dan perusahaan yang tidak berkembang, yang nantinya menghambat pasar keuangan dalam peran mereka untuk mengalokasikan tabungan menjadi alternatif investasi lainnya dalam perekonomian (Mankiw, 2018).

\section{Pendapatan}

Menurut Keynes pendapatan yaitu perubahan pada jumlah faktor produksi yang digunakan dan perubahan kemampuan setiap unit faktor produksi tersebut menghasilkan pendapatan. Pendapatan industri adalah pendapatan yang diperoleh karena telah mengorganisasikan seluruh faktor produksi yang dikelolanya (Helmalia, 2018) .

Menurut (Saputri \& Dewi, 2020) pendapatan usaha merupakan pendapatan yang berasal dari aktivitas utama perusahaan sebagaimana tersebut dalam anggaran dasar perusahaan. Pendapatan usaha diperoleh dari 3 (tiga) pos utama, yaitu:

a. Pendapatan Sewa Modal merupakan Pendapatan yang didapatkan dari kegiatan perusahaan dalam usaha distribusi kredit tunai

b. Pendapatan administrasi merupakan pendapatan yang diperoleh sebagai pengganti biaya prosedur pemberian kredit

c. Pendapatan Operasional Lainnya termasuk fee based payment (FBI) dari layanan cicilan dan pembayaran, serta layanan lain yang terkait dengan penyimpanan produk dan penaksiran produk. Selain itu, pendapatan usaha lainnya juga berasal dari pelayanan pengelolaan pengembangan aset dan dari pengelolaan Tabungan Emas yang merupakan item baru pada tahun 2016

\section{Pembiyaan Rahn}


Secara istilah, rahn yaitu menjadikan suatu barang sebagai jaminan suatu hutang yang dapat digunakan sebagai pembayaran jika tidak dapat melunasi hutang tersebut. Artinya rahn memiliki arti yang sama dengan borg, yaitu sesuatu yang digadaikan oleh orang yang mempunyai hutang dan dapat disita jika debitur tidak dapat membayar hutangnya (Janwari, 2015).. Menurut (Amir, 2015) ada beberapa pengertian yang dikemukakan oleh para peneliti fiqh, antara lain:

a. Mazhab Maliki mendeskripsikan rahn sebagai harta yang mengikat.

b. Peneliti Hanafi mendeskripsikan rahn dengan "menjadikan sesuatu (barang) sebagai jaminan atas hak (piutang) yang dapat digunakan sebagai pembayar hak (piutang) tersebut, baik seluruhnya maupun sebagian".

c. Ulama madzhab Syafi'i dan Hanbali mendeskripsikan rahn dalam arti perjanjian, khususnya menjadikan barang sebagai jaminan hutang yang dapat dijadikan sebagai pembayar utang jika pemegang utang tidak mampu membayar hutang tersebut.

Payung hukum gadai syariah dalam memenuhi standar syariah diarahkan oleh Fatwa DSN MUI No. 25/DSN-MUI/III/2002 tentang Rahn. Disimpulkan bahwa jaminan dengan menggadaikan barang sebagai jaminan atas suatu hutang sebagai rahn dapat diterima. Dengan dikeluarkannya fatwa DSN MUI tersebut menjadi acuan dan legitimasi yang komprehensif bagi lembaga keuangan syariah di Indonesia (L. Roficoh, 2018).

Pembiayaan adalah tugas utama lembaga keuangan, Tugas pokok lembaga keuangan yaitu pembiayaan. termasuk lembaga keuangan Islam melalui pemberian dana kepada masyarakat yang sedang kesulitan atau membutuhkan. Pembiayaan tersebut sebenarnya terdiri dari beberapa macam dan variasi. Semuanya menjadi kehendak bagi masyarakat atau pihak yang membutuhkan dalam menentukan variasi pembiayaan mana yang akan digunakan. kegiatan yang muncul di masyarakat akhir-akhir ini yaitu terjadinya akad pembiayaan yang didalamnya terdapat rahn (gadai). Sebagai suatu hal yang baru, jelas bahwa pembiayaan yang disertai Rahn sebenarnya belum memiliki landasan hukum secara syar'i. Maka dari itu untuk menjawab persoalan yang terjadi di masyarakat atas kondisi tersebut Majelis Ulama Indonesia, Dewan Syariah Nasional mengeluarkan fatwa mengenai pembiayaan yang disertai Rahn.

\section{B. Perbandingan Penelitian Terdahulu}

Penelitian tentang Pengaruh Pengaruh Tingkat Inflasi Dan Pendapatan Usaha Pegadaian Terhadap Pembiayaan Rahn Pada Pegadaian Syariah sudah banyak dilakukan oleh peneliti sebelumnya seperti penelitian yang dilakukan oleh peneliti-peneliti sebagai berikut:

1. Pengaruh Pendapatan Pegadaian, Dan Harga Emas Terhadap Penyaluran Pembiayaan Rahn (Sudi kasus pada pada PT. Pegadaian Syariah Cabang Ternate) (Mamulati, 2020)

Permasalahan yang dibahas dalam penelitian ini adalah seberapa besar pengaruh pendapatan pegadaian, harga emas terhadap penyaluran pembiyaan rahn pada PT. Pegadaian Syariah Cabang Ternate. Metode Analisis data yang digunakan yaitu regresi berganda. Jenis data yang digunakan dalam penelitian ini merupakan data sekunder berupa laporan keuangan tahun 2015-2018. Hasil dari pengujian ini menunjukkan bahwa Pendapatan Pegadaian secara parsial berpengaruh terhadap penyaluran pembiayaan rahn PT. Pegadaian Syariah Cabang Ternate. Sementara Harga emas secara parsial berpengaruh terhadap penyaluran pembiayaan rahn PT. Pegadaian Syariah Cabang Ternate. Selain itu, secara 
simultan pendapatan pegadaian dan harga emas berpengaruh terhadap penyaluran pembiayaan rahn PT. Pegadaian Syariah Cabang Ternate.

Perbedaan penelitian terdahulu dengan penelitian saat ini adalah penelitian terdahulu menganalisis atau mengkaji pengaruh pendapatan pegadaian, harga emas terhadap penyaluran pembiyaan rahn. Sedangkan pada penelitian saat ini peneliti menganalisis atau mengkaji pengaruh tingkat inflasi dan pendapatan usaha pegadaian terhadap pembiayaan Rahn. Perbedaan selanjutnya dari segi lokasi, penelitian terdahulu melakukan penelitian pada PT. Pegadaian Syariah Cabang Ternate. Sedangkan peneliti saat ini di Pegadaian syariah Indonesia.

\section{Pengaruh Pendapatan Pegadaian, Harga} Emas, Tingkat inflasi terhadap penyaluran pembiayaan rahn. (Studi kasus pada PT. Pegadaian cabang Bonder Lombok Tengah) (Hariyanti et al., 2019).

Penelitian ini bertujuan untuk mengetahui apakah terdapat pengaruh pendapatan pegadaian, harga emas, inflasi terhadap penyaluran pembiayaan rahn. jenis penelitian yang digunakan dalam penelitian ini adalah penelitian kuantitatif dengan sumber data yang dipakai adalah data sekunder. Strategi yang digunakan dalam penelitian ini yaitu teknik pengambilan sampel dilakukan dengan menggunakan metode purposive sampling. Prosedur pengujian data yang digunakan dalam penelitian ini yaitu model regresi linier berganda. Hasil penelitian ini menunjukan bahwa secara simultan atau parsial variable Pendapatan pegadaian berpengaruh signifikan terhadap penyaluran pembiayaan rahn. Harga emas berpengaruh signifikan terhadap penyaluran pembiayaan rahn. Tingkat inflasi berpengaruh signifikan terhadap penyaluran pembiayaan rahn.
Perbedaan penelitian terdahulu dan penelitian saat ini adalah bahwa penelitian terdahulu menganalisis dan mengkaji mengenai pengaruh pendapatan pegadaian, harga emas dan tingkat inflasi terhadap penyaluran pembiayaan rahn. Sedangkan pada penelitian saat ini peneliti menganalisis atau mengkaji mengenai pengaruh tingkat inflasi dan pendapatan usaha pegadaian terhadap pembiayaan Rahn. Perbedaan selanjutnya dari metode penelitian dan dari segi lokasi penelitian, penelitian terdahulu melakukan penelitian pada PT. Pegadaian cabang Bondor Lombok Tengah. Sedangkan peneliti saat ini di pegadaian syariah indonesia.

3. Pengaruh Inflasi, Harga Emas dan Jumlah Nasabah Terhadap Penyaluran Pembiayaan ar-rahn pada PT Pegadaian Syariah unit geudong (Hamdani et al., 2020) .

Permasalahan yang dibahas dalam penelitian ini adalah Untuk mengetahui seberapa besar inflasi, harga emas dan jumlah nasabah atas pinjaman pembiayaan ar-rahn di Pegadaian Syariah Unit Geudong. Metode yang digunakan untuk menganalisis hubungan antara variabel bebas dengan variabel terikat yaitu dengan metode regresi linier berganda dan uji asumsi klasik. Penelitian ini merupakan penelitian kuantitatif penelitian dengan melakukan analisis data kuantitatif. Teknik pengumpulan data penelitian ini adalah dengan mengumpulkan data sekunder yang sudah jadi. Hasil dari penelitian ini menunjukkan bahwa inflasi, harga emas dan jumlah nasabah berpengaruh signifikan terhadap pembiayaan pinjaman ar-rahn secara bersamaan. harga emas dan jumlah nasabah berpengaruh terhadap pembiayaan pinjaman Ar-Rahn secara parsial. Hasil penelitian ini diharapkan dapat bermanfaat bagi Pegadaian Syariah, khususnya PT Pegadaian Syariah Unit Geudong untuk meningkatkan kinerja di masa depan. 
Perbedaan peneliti terdahulu dengan penelitian saat ini adalah penelitian terdahulu menganalisis dan mengkaji mengenai pengaruh inflasi, harga emas dan jumlah nasabah atas pinjaman pembiayaan ar-rahn. Sedangkan pada penelitian saat ini peneliti menganalisis atau mengkaji mengenai pengaruh tingkat inflasi dan pendapatan usaha pegadaian terhadap pembiayaan Rahn. Perbedaan selanjutnya dari metode penelitian dan dari segi lokasi penelitian, penelitian terdahulu melakukan penelitian pada PT Pegadaian Syariah Unit Geudong. Sedangkan peneliti saat ini di Pegadaian syariah Indonesia.

4. Pengaruh Pendapatan Pegadaian, Tingkat NPL, Tingkat Inflasi dan Harga Emas Tehadap Penyaluran Pembiayaan Gadai Rahn Pada Pegadaian Syariah (Aulia \& Setiawan, 2020)

Penelitian ini bertujuan untuk mengetahui Pendapatan Pegadaian, Tingkat NPL, Tingkat Inflasi dan Harga Emas Tehadap Penyaluran Pembiayaan Gadai Rahn pada Pegadaian Syariah di Indonesia. Metode penelitian ini adalah metode regresi linier berganda dan uji asumsi klasik. Data yang digunakan dalam pengujian ini merupakan data sekunder yang didapatkan dari laporan keuangan dan laporan tahunan milik pegadaian yang diperoleh dari website resmi pegadaian, data statistik tingkat inflasi yang diperoleh dari website resmi Bank Indonesia dan data statistik harga emas yang didapat dari website Harga Emas. Hasil penelitian ini menunjukkan bahwa secara parsial pendapatan, tingkat NPL dan harga emas berpengaruh terhadap penyaluran pembiaayan gadai rahn tetapi pada variabel tingkat inflasi tidak berpengaruh terhadap penyaluran pembiayaan gadai rahn yang artinya setiap peningkatan atau penurunan nilai tingkat inflasi tidak akan mempengaruhi besarnya penyaluran gadai rahn. Secara simultan atau bersama-sama Pendapatan. tingkat NPL, tingkat inflasi, dan harga emas berpangaruh terhadap penyaluran pembiayaan gadai rahn.

Perbedaan peneliti terdahulu dengan penelitian saat ini adalah penelitian terdahulu menganalisis dan mengkaji mengenai pengaruh Pendapatan Pegadaian, Tingkat NPL, Tingkat Inflasi dan Harga Emas Tehadap Penyaluran Pembiayaan Gadai Rahn pada Pegadaian Syariah di Indonesia pada tahun tahun 2008-2018. Sedangkan pada penelitian saat ini peneliti hanya menganalisis atau mengkaji mengenai pengaruh tingkat inflasi dan pendapatan usaha pegadaian terhadap pembiayaan Rahn pada Pegadaian Syariah tahun 2011-2020.

\section{Pengaruh Pendapatan Terhadap} Pembiayaan Gadai (Rahn) Pada Pegadaian Syariah Way Halim 2016-2018 (Saputri \& Dewi, 2020).

Permasalahan yang dibahas dalam penelitian ini adalah Untuk mengetahui bagaimana pengaruh pendapatan terhadap pembiayaan gadai (rahn). Data sekunder yang digunakan adalah data pendapatan dan pembiayaan gadai yang diambil langsung dari Pegadaian Syariah. Dengan menggunakan metode kuantitatif karena data yang ada berupa data angka atau numerik yang diperoleh dari Pegadaian Syariah dan data diskrit. Data sekunder yang digunakan dalam laporan ini merupakan data pendapatan dan pembiayaan gadai yang diambil langsung dari Pegadaian Syariah Way Halim. Hasil penelitian ini menujukan bahwa pengaruh pendapatan terhadap pembiayaan gadai (rahn) dilihat dari analisis regresi linier sederhana yang diperoleh dari nilai koefisien regresi yaitu sebesar $(-0,229)$ dan tingkat signifikansi sebesar 0,000, menunjukan bahwa variabel pendapatan memiliki pengaruh negatif dan signifikan terhadap pembiayaan gadai (rahn) di Pegadaian Syariah Way Halim. Hal ini 
mengindikasi bahwa jika jumlah pendapatan meningkat, maka pembiayaan gadai (rahn) akan mengalami penurunan.

Perbedaan penelitian terdahulu dengan penelitian ini adalah rumusan masalahnya. Penelitian terdahulu berfokus pada pengaruh pendapatan dan penyaluran kredit tanpa ada pengaruh eksogen, sedangkan penelitian ini memiliki data eksogen yang akan diteliti pengaruhnya dengan faktor Y. Perbedaan selanjutnya dari segi lokasi penelitian, penelitian terdahulu melakukan penelitian pada Pegadaian Syariah Way Halim. Sedangkan peneliti saat ini di Pegadaian syariah Indonesia.

\section{Analisis Pengaruh Jumlah nasabah,} Pendapatan dan Harga Emas Terhadap Tingkat Penyaluran Gadai Syariah (rahn) pada PT. Pegadaian (PERSERO) tahun 2012-2017 (Rubianti, 2017).

Penelitian ini bertujuan untuk mengetahui bagaimana pengaruh Jumlah nasabah, Pendapatan pegadaian Syariah, dan Harga Emas Terhadap penyaluran Gadai Syariah (Rahn) di PT Pegadaian. Data yang digunakan dalam penelitian ini berupa data data time series periode 2012-2017. Penelitian ini menggunakan metode analisis regresi linier berganda dengan menggunakan program komputer EViews 9.0, dan telah dibantu oleh microsoft excel 2013. Hasil penelitian menunjukkan secara parsial Jumlah Nasabah Pegadaian Syariah berpengaruh signifikan terhadap Gadai Syariah (Rahn) dengan sig. $0,0000<0,05$. Pendapatan Usaha Gadai Syariah berpengaruh signifikan terhadap Gadai Syariah (Rahn) dengan sig. 0,0000 < 0,05. Harga Emas berpengaruh signifikan terhadap Gadai Syariah. (Rahn) dengan tanda sig. 0,0302 > 0,05. Hasil penelitian menunjukkan bahwa Jumlah Nasabah Pegadaian Syariah, Pendapatan pegadaian, dan Harga Emas, secara bersamaan atau bersama-sama memiliki pengaruh yang signifikan Pengaruhnya terhadap Gadai Syariah (Rahn) dengan sig. 0,000<0,05'.

Perbedaan peneliti terdahulu dengan penelitian saat ini adalah penelitian terdahulu menganalisis dan mengkaji mengenai pengaruh jumlah nasabah, pendapatan dan harga emas terhadap tingkat penyaluran gadai syariah pada PT. Pegadaian (PERSERO) sedangkan pada penelitian saat ini peneliti menganalisis dan mengkaji mengenai pengaruh tingkat inflasi dan pendapatan usaha terhadap pembiayaan rahn. Perbedaan selanjutnya terdapat pada aplikasi pengolah data peneliti terdahulu menggunakan program komputer EViews 9.0 sedangkan peneliti saat ini menggunakan program aplikasi SPSS versi 22.

\section{METODOLOGI PENELITIAN}

Jenis penelitian ini penulis menggunakan metode deskriptif kuantitatif yang bermaksud untuk menggambarkan kejadian pada objek penelitian sebagaimana adanya dan pengambilan keputusan didasarkan pada hasil analisis statistik. Dilihat dari permasalahan yang diteliti penelitian ini bersifat asosiatif yang bertujuan untuk menanyakan hubungan antara dua variabel atau lebih.

Sumber data yang digunakan dalam penelitian ini merupakan data sekunder karena peneliti tidak mengumpulkan sendiri. Data yg diperoleh melainkan data yang telah diterbitkan atau dipublikasi oleh pihak tertentu. Teknik pengumpulan data dalam penelitian ini adalah studi dokumentasi, dengan cara melakukan penelusuran data melalui media online seperti internet lalu dikumpulkan dan disatukan. Data berupa laporan tahunan pegadaian pada tahun 20112020 dan data tingkat inflasi pada tahun 2011-2020 yang diperoleh melalui website www.bps.go.id dan www.pegadaian.co.id

Model analisis data dalam penelitian ini menggunakan metode analisis regresi linear berganda yang perhitungannya menggunakan 
SPSS versi 22. SPSS membantu untuk mengolah, menghitung dan analisis data secara statistik, berperan dalam mengukur besarnya pengaruh antara variabel independen yaitu tingkat inflasi dan pendapatan pegadaian terhadap dependent yaitu pembiayaan rahn.

\section{HASIL DAN PEMBAHASAN}

Dalam melakukan analisis statistik ada beberapa langkah pengujian yang harus dilakukan. Adapun langkah-langkah tersebut yaitu sebagai berikut:

\section{A. Uji Asumsi Klasik}

Uji Asumsi Klasik dalam penelitian ini meliputi Uji Normalitas, Uji Multikolinearitas, Uji Heteroskedastisitas dan Uji Autokorelasi. Uji normalitas bertujuan untuk mengetahui distribusi data dalam suatu variabel yang akan digunakan dalam sebuah penelitian apakah data layak atau tidak untuk dianalisis (Rosadi \& Waluyo, 2017). Multikolinearitas bertujuan untuk menguji apakah model regresi ditemukan adanya korelasi antar variabel bebas (independen) (Christine et al., 2019). Model regresi yang baik seharusnya tidak terjadi korelasi di antara variabel independen, dan heteroskedastisitas bertujuan menguji apakah dalam model regresi terjadi ketidaksamaan variance dari residual satu pengamatan ke pengamatan yang lain. Model regresi yang baik adalah tidak terjadi Heteroskedastisitas (Almunawwaroh \& Marliana, 2018). Uji autokorelasi bertujuan untuk menguji apakah dalam model regresi terdapat korelasi di antara kesalahan pengganggu dalam periode tertentu. Salah satu teknik untuk mendeteksi adanya autokorelasi adalah dengan menggunakan uji Durbin-Watson (D-W) (Rasmikayati \& Saefudin, 2018).

1. Uji Normalitas

Tabel 4.1

Uji Normalitas

\begin{tabular}{|c|c|c|}
\hline \multicolumn{3}{|c|}{ One-Sample Kolmogorov-Smirnov Test } \\
\hline & & $\begin{array}{l}\text { Unstandardized } \\
\text { Residual }\end{array}$ \\
\hline \multicolumn{2}{|l|}{$\mathrm{N}$} & 10 \\
\hline \multirow[t]{2}{*}{ Normal Parameters ${ }^{\mathrm{a}, \mathrm{b}}$} & Mean & .0000000 \\
\hline & $\begin{array}{l}\text { Std. } \\
\text { Deviation }\end{array}$ & $\begin{array}{r}1249104.964789 \\
13 \\
\end{array}$ \\
\hline \multirow{3}{*}{$\begin{array}{l}\text { Most Extreme } \\
\text { Differences }\end{array}$} & Absolute & .174 \\
\hline & Positive & .088 \\
\hline & Negative & -.174 \\
\hline \multicolumn{2}{|l|}{ Test Statistic } & .174 \\
\hline \multicolumn{2}{|l|}{ Asymp. Sig. (2-tailed) } & $.200^{\mathrm{c}, \mathrm{d}}$ \\
\hline \multicolumn{3}{|c|}{ a. Test distribution is Normal. } \\
\hline \multicolumn{3}{|l|}{ b. Calculated from data. } \\
\hline \multicolumn{3}{|c|}{ c. Lilliefors Significance Correction. } \\
\hline \multicolumn{3}{|c|}{ d. This is a lower bound of the true significance. } \\
\hline
\end{tabular}

(Sumber: hasil olah data SPSS versi 22, 2021)

Berdasarkan tabel output SPSS tersebut, diketahui bahwa 0,200 lebih besar dari 0,05. Maka sesuai dengan dasar pengambilan keputusan dalam uji normalitas KolmogorovSmirnov di atas, dapat disimpulkan bahwa data berdistribusi normal. Dengan demikian, asumsi atau persyaratan normalitas dalam model regresi sudah terpenuhi

2. Uji Multikolinearitas

Tabel 4.2

Uji Multikolinearitas

\begin{tabular}{|c|c|c|c|c|c|c|c|c|}
\hline \multicolumn{9}{|c|}{ Coefficients $^{a}$} \\
\hline & \multirow{2}{*}{ Model } & \multicolumn{2}{|c|}{$\begin{array}{c}\text { Unstandardiz } \\
\text { ed } \\
\text { Coefficients }\end{array}$} & \multirow{2}{*}{ 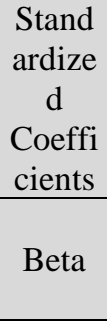 } & \multirow{2}{*}{$\mathrm{t}$} & \multirow{2}{*}{ Sig. } & \multicolumn{2}{|c|}{$\begin{array}{c}\text { Collineari } \\
\text { ty } \\
\text { Statistics }\end{array}$} \\
\hline & & B & $\begin{array}{l}\text { Std. } \\
\text { Error }\end{array}$ & & & & $\begin{array}{c}\text { Tole } \\
\text { ranc } \\
\mathrm{e}\end{array}$ & VIF \\
\hline 1 & $\begin{array}{l}\text { (Con } \\
\text { stant) }\end{array}$ & $\begin{array}{r}50845 \\
50.74 \\
1\end{array}$ & $\begin{array}{r}21501 \\
24.69 \\
4\end{array}$ & & $\begin{array}{r}2.3 \\
65\end{array}$ & $\begin{array}{r}.05 \\
0\end{array}$ & & \\
\hline & $\begin{array}{l}\text { Inflas } \\
\mathrm{i}\end{array}$ & $\begin{array}{r}- \\
7643 . \\
138\end{array}$ & $\begin{array}{r}25362 \\
7.136\end{array}$ & -.004 & $\begin{array}{r}-.03 \\
0\end{array}$ & $\begin{array}{r}.97 \\
7\end{array}$ & .662 & $\begin{array}{r}1.5 \\
10\end{array}$ \\
\hline & $\begin{array}{l}\text { Pend } \\
\text { apata } \\
n\end{array}$ & .835 & .117 & .955 & $\begin{array}{r}7.1 \\
41\end{array}$ & $\begin{array}{r}.00 \\
0\end{array}$ & .662 & $\begin{array}{r}1.5 \\
10\end{array}$ \\
\hline
\end{tabular}

a. Dependent Variable: Pembiayaan Rahn

(Sumber: hasil olah data SPSS versi 22, 2021) 
Berdasarkan hasil Uji Multikolinearitas diatas menunjukan bahwa adanya kemiripan antara variabel Inflasi dan Pendapatan pegadaian yang berarti kedua variabel tersebut mempunyai korelasi yang kuat. Selain itu VIF dari Uji asumsi klasik ini adalah 1.510 yang berarti nilainya masih di antara 1-10. Sehingga dapat disimpulkan bahwa tidak terjadi multikolinearitas.

3. Uji Heteroskedastisitas

Grafik 4.3

Uji heteroskedastisitas

Scatterplot

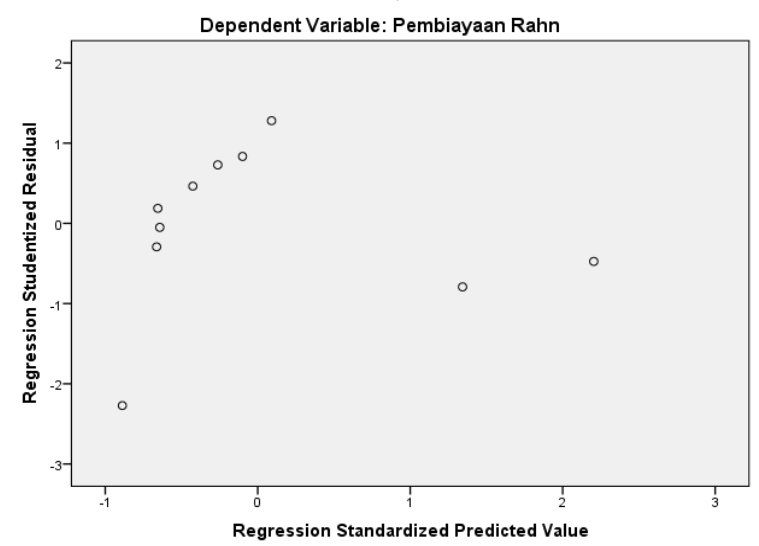

(Sumber: hasil olah data SPSS versi 22, 2021)

Berdasarkan hasil uji heteroskedastisitas, yang ditunjukan oleh grafik scaterplot diatas, terlihat bahwa titik-titik menyebar dan tidak hanya mengumpul di atas atau dibawah serta tidak membentuk pola tertentu yang jelas. Sehingga dapat disimpulkan bahwa tidak terjadi Heteroskedastisitas.

4. Uji Autokorelasi

Tabel 4.4

Uji Autokorelasi

\begin{tabular}{|c|c|c|c|c|c|}
\hline \multicolumn{7}{|c|}{ Model Summary } \\
\hline Model & $\mathrm{R}$ & $\mathrm{R}$ & Adjusted R & $\begin{array}{c}\text { Std. Error } \\
\text { of the } \\
\text { Stimate }\end{array}$ & $\begin{array}{c}\text { Durbin- } \\
\text { Watson }\end{array}$ \\
\hline 1 & $.958^{\mathrm{a}}$ & .917 & .893 & $\begin{array}{c}1416351.89 \\
9\end{array}$ & .967 \\
\hline
\end{tabular}

a. Predictors: (Constant), Pendapatan, Inflasi

b. Dependent Variable: Pembiayaan Rahn
(Sumber: hasil olah data SPSS versi 22, 2021)

Berdasarkan output SPSS di atas, diketahui nilai Durbin Watson sebesar 0,967. Nilai ini terletak antara dL 0,697 dan dU 1,641 sehingga tidak ada kesimpulan yang pasti tentang ada atau tidaknya gejala autokorelasi dari data tersebut. Untuk mengatasi adanya gejala autokorelasi, penulis menggunakan metode Uji Run Test. Berikut ini hasil pengolahan dengan metode Uji Run Test:

Tabel 4.5

Uji Run Test

\begin{tabular}{|l|r|}
\hline \multicolumn{2}{|c|}{ Runs Test } \\
\hline & $\begin{array}{c}\text { Unstandardized } \\
\text { Residual }\end{array}$ \\
\hline Test Value $^{\mathrm{a}}$ & 69659.55945 \\
\hline Cases < Test Value & 5 \\
\hline Cases >= Test Value & 5 \\
\hline Total Cases & 10 \\
\hline Number of Runs & 3 \\
\hline Z & -1.677 \\
\hline Asymp. Sig. (2-tailed) & .094 \\
\hline a. Median &
\end{tabular}

(Sumber: hasil olah data SPSS versi 22, 2021)

Berdasarkan tabel hasil Uji Autokorelasi di atas dapat terlihat bahwa nilai Asymp. Sig. (2tailed) sebesar 0,094 lebih besar > dari 0,05, maka dapat disimpulkan bahwa tidak terdapat gejala atau masalah autokorelasi. Dengan demikian, masalah autokorelasi yang tidak dapat terselesaikan dengan durbin watson dapat teratasi melalui uji run test sehingga analisis regresi linear dapat dilanjutkan.

\section{B. Uji Hipotesis}

1. Analisis Regresi Linier Berganda

Uji Analisis regresi linier berganda sendiri menjelaskan tentang hubungan antar variabel, seperti variabel terikat dan variabel bebas. Variabel terikat di dalam analisis regresi sering juga disebut sebagai variabel respon

EKSISBANK (Ekonomi Syariah dan Bisnis Perbankan), Volume 5, Nomor 2, Desember 2021 http://journal.sties-purwakarta.ac.id/index.php/EKSISBANK/ 
dan variabel bebas sering disebut sebagai variabel prediktor (Wibisono et al., 2019).

Tabel 4.6

Hasil Analisis Regresi Linier Berganda

\begin{tabular}{|c|c|c|c|c|c|c|}
\hline \multicolumn{7}{|c|}{ Coefficients $^{a}$} \\
\hline \multirow{2}{*}{\multicolumn{2}{|c|}{ Model }} & \multicolumn{2}{|c|}{$\begin{array}{c}\text { Unstandardized } \\
\text { Coefficients }\end{array}$} & $\begin{array}{c}\text { Standardi } \\
\text { zed } \\
\text { Coefficien } \\
\text { ts } \\
\end{array}$ & \multirow[b]{2}{*}{$\mathrm{T}$} & \multirow[b]{2}{*}{ Sig. } \\
\hline & & B & Std. Error & Beta & & \\
\hline 1 & $\begin{array}{l}\text { Constan } \\
\text { t) } \\
\end{array}$ & $\begin{array}{r}5084550 . \\
741 \\
\end{array}$ & \begin{tabular}{|r|}
2150124. \\
694 \\
\end{tabular} & & 2.365 & .050 \\
\hline & Inflasi & 7643.138 & \begin{tabular}{|r|}
253627.1 \\
36 \\
\end{tabular} & -.004 & -.030 & .977 \\
\hline & $\begin{array}{l}\text { Pendapat } \\
\text { an }\end{array}$ & .835 & .117 & .955 & 7.141 & .000 \\
\hline
\end{tabular}

a. Dependent Variable: Pembiayaan Rahn

(Sumber: Hasil olah data SPSS 22,2021)

Berdasarkan hasil pengujian regresi linier berganda pada tabel diatas, maka didapat persamaan regresi sebagai berikut: $\mathrm{Y}=$ $5084550.741-7643.138+0.835$

1) Konstanta yang diperoleh dari persamaan regresi diatas sebesar 5084550.741 menyatakan bahwa jika variabel inflasi dan variabel pendapatan bernilai 0 , maka dapat diartikan struktur pembiayaan Rahn akan bernilai sebesar 5084550.741.

2) Koefisien regresi dari variabel Inflasi bernilai negatif yaitu sebesar 7643.138, hal tersebut dapat diartikan bahwa jika variabel inflasi mengalami kenaikan $1 \%$, maka pembiayaan rahn akan mengalami penurunan sebesar 7643.138. koefisien bernilai negatif artinya terjadi hubungan negatif antara Inflasi dengan pembiayaan rahn.

3) Koefisien regresi dari variabel pendapatan usaha bernilai sebesar 0.835. hal tersebut dapat diartikan bahwa setiap kenaikan $1 \%$ variabel pendapatan usaha maka tingkat pembiayaan rahn akan mengalami kenaikan sebesar 0.835

2. Uji Koefisien Determinasi (R2)
Koefisien determinasi (R2) pada intinya mengukur seberapa jauh kemampuan model dalam menerangkan variasi variabel independen. Nilai koefisien determinasi adalah antara nol dan satu. Nilai R2 yang kecil berarti kemampuan variabel-variabel independen dalam menjelaskan variasi variabel dependen sangat terbatas (Rasmikayati \& Saefudin, 2018).

Tabel 4.7

Uji Koefisien Determinasi (R2)

\begin{tabular}{|c|c|c|c|c|}
\hline \multicolumn{5}{|c|}{ Model Summary $^{\mathbf{b}}$} \\
\hline Model & $\mathrm{R}$ & $\mathrm{R}$ Square & $\begin{array}{c}\text { Adjusted } \mathrm{R} \\
\text { Square }\end{array}$ & $\begin{array}{c}\text { Std. Error of } \\
\text { the Estimate }\end{array}$ \\
\hline 1 & $.958^{\mathrm{a}}$ & .917 & .893 & 1416351.899 \\
\hline
\end{tabular}

a. Predictors: (Constant), Pendapatan, Inflasi

b. Dependent Variable: Pembiayaan Rahn

(Sumber: Hasil olah data SPSS 22,2021)

Berdasarkan tabel diatas dapat diketahui bahwa besarnya adjusted R Square adalah 0,893. Hal ini menunjukkan bahwa kemampuan variabel bebas (independen) dalam penelitian untuk menerangkan variabel terikat (dependen) adalah sebesar $89,3 \%$, sedangkan $10,7 \%$ nya dijelaskan oleh faktor lain yang tidak dijelaskan dalam penelitian ini.

\section{Uji Parsial (t)}

Uji parsial $(\mathrm{t})$ bertujuan untuk mengetahui seberapa jauh pengaruh dari variabel independen $(\mathrm{X})$ terhadap variabel dependen (Y) secara parsial. Pengujian hipotesis akan dilakukan dengan menggunakan tingkat signifikansi parametik individual sebesar $0,05(\mathrm{a}=5 \%)$.

Tabel 4.8

Hasil Uji parsial (t)

\begin{tabular}{|c|c|c|c|c|c|}
\hline \multicolumn{4}{|c|}{ Coefficients $^{\text {a }}$} & \\
\hline \multirow{3}{*}{ Model } & \multicolumn{2}{|c|}{$\begin{array}{c}\text { Unstandardized } \\
\text { Coefficients }\end{array}$} & $\begin{array}{c}\text { Standardi } \\
\text { zed } \\
\text { Coefficie } \\
\text { nts }\end{array}$ & T & Sig. \\
\cline { 2 - 4 } & B & $\begin{array}{c}\text { Std. } \\
\text { Error }\end{array}$ & Beta & & \\
\hline
\end{tabular}




\begin{tabular}{|c|c|c|c|c|c|c|}
\hline 1 & $\begin{array}{c}\text { Constan } \\
\mathrm{t})\end{array}$ & $\begin{array}{c}5084550 . \\
741\end{array}$ & $\begin{array}{c}2150124 \\
694\end{array}$ & & 2.365 & .050 \\
\cline { 2 - 7 } & Inflasi & $\begin{array}{c}- \\
7643.138\end{array}$ & $\begin{array}{c}253627.1 \\
36\end{array}$ & -.004 & -.030 & .977 \\
\cline { 2 - 7 } & $\begin{array}{c}\text { Pendapat } \\
\text { an }\end{array}$ & .835 & .117 & .955 & 7.141 & .000 \\
\hline
\end{tabular}

a. Dependent Variable: Pembiayaan Rahn

(Sumber: Hasil olah data SPSS 22,2021)

Sebelum menyimpulkan hipotesis yang diterima atau dit Terlebih dahulu menentukan tabel dengan signifikan 5\% berdasarkan uji 2 sisi dan derajat kebebasan (df) $(\alpha / 2 ; n-k-1)$ atau $(0,05 / 2 ; 10-2-1)=(0,025 ; 7)$ Dengan pengujian dua sisi tersebut hasil yang diperoleh untuk $t_{\text {tabel }}$ adalah 2,365

Dari hasil uji signifikan parametrik individual (uji t) pada variabel Inflasi menghasilkan nilai $t_{\text {hitung }}$ sebesar $-0,030$, artinya $t_{\text {tabel }}$ lebih besar dari $t_{\text {hitung }}(2,365>$ 0,030) serta sig.0,977>0,05. Dari hasil tersebut maka Ho diterima inflasi mempunyai pengaruh negatif dan inflasi tidak berpengaruh secara signifikan terhadap pembiayaan rahn.

Sedangkan dari hasil uji signifikan parametik individual (uji t) pada variabel pendapatan pegadaian menghasilkan thitung sebesar 7,141 artinya thitung lebih besar dari $t_{\text {tabel }}(7,141>2,365)$ serta nilai signifikan $0,000<0,05$. Dari hasil tersebut berarti Ho ditolak pendapatan pegadaian mempunyai pengaruh positif dan pendapatan pegadaian berpengaruh secara signifikan terhadap pembiayaan Rahn.

\section{Uji Simultan (f)}

Uji Statistik F ini bertujuan untuk menunjukkan apakah semua variabel independen yang dimasukkan dalam model mempunyai pengaruh secara bersama-sama terhadap variabel dependen/terikat. Pada pengujian ini juga menggunakan ketentuan jika nilai $F$ hitung lebih besar dari pada $F$ tabel maka Ho ditolak. Pengujian ini juga menggunakan tingkat signifikansi sebesar 5\% atau 0,05 (Siti Nurlaela, 2017)
Tabel 4.9

Hasil Uji Simultan (f)

\begin{tabular}{|c|c|c|c|c|c|c|}
\hline \multicolumn{7}{|c|}{ ANOVA $^{a}$} \\
\hline \multicolumn{2}{|c|}{ Model } & $\begin{array}{l}\text { Sum of } \\
\text { Squares }\end{array}$ & df & $\begin{array}{l}\text { Mean } \\
\text { Square }\end{array}$ & $\mathrm{F}$ & Sig. \\
\hline 1 & $\begin{array}{l}\text { Regres } \\
\text { sion }\end{array}$ & $\begin{array}{r}155259064 \\
067996.800\end{array}$ & 2 & $\begin{array}{r}77629532 \\
033998.40 \\
0\end{array}$ & $\begin{array}{r}38.69 \\
8\end{array}$ & $\begin{array}{r}.000 \\
\mathrm{~b}\end{array}$ \\
\hline & $\begin{array}{l}\text { Residu } \\
\text { al }\end{array}$ & $\begin{array}{r}140423689 \\
17547.580\end{array}$ & 7 & $\begin{array}{r}20060527 \\
02506.797\end{array}$ & & \\
\hline & Total & $\begin{array}{r}169301432 \\
985544.400\end{array}$ & 9 & & & \\
\hline
\end{tabular}

a. Dependent Variable: Pembiayaan Rahn

b. Predictors: (Constant), Pendapatan, Inflasi

(Sumber: hasil olah data SPSS versi 22, 2021)

Sebelum membuat kesimpulan disini penulis menjabarkan terlebih dahulu $f_{\text {tabel }}$ nya, yaitu dengan rumus (k:n-k), k= merupakan jumlah variabel bebas, sedangkan $n$ merupakan jumlah sampel penelitian. Jadi k$2, n=7$, selanjutnya masukkan ke dalam rumus $(2: 10-2)=(2: 8)$ nilai ini kemudian kita jadikan acuan untuk mengetahui nilai $f_{\text {tabel }}$ pada distribusi nilai $f_{\text {tabel }}$ statistik. Maka diketahui nilai $\mathrm{f}_{\text {tabel }}$ sebesar 4,46 karena nilai $\mathrm{f}_{\text {hitung }} 38.698$ lebih besar dari nilai $\mathrm{f}_{\text {tabel }}$ dan nilai signifikansi sebesar 0,000 jauh lebih kecil dari 0,05. Maka dapat ditarik kesimpulan bahwa variabel bebas inflasi dan pendapatan pegadaian (Secara simultan) berpengaruh terhadap variabel pembiayaan rahn.

\section{Pengaruh tingkat Inflasi terhadap pembiyaan Rahn (Y)}

$\left(\mathbf{X}_{1}\right)$

Berdasarkan hasil pengujian regresi menunjukan inflasi memiliki nilai koefisien negatif yaitu sebesar - 7643.138 serta nilai $t_{\text {hitung }}$ sebesar $-0,030$, artinya $t_{\text {tabel }}$ lebih besar dari thitung $(2,365>-0,030)$ dan sig.0,977>0,05. Dari hasil tersebut maka Ho diterima inflasi mempunyai pengaruh negatif dan inflasi tidak berpengaruh secara signifikan terhadap pembiayaan rahn. Inflasi didefinisikan sebagai kenaikan harga barang dan jasa secara umum dan berkelanjutan. Semakin tinggi tingkat inflasi maka daya beli masyarakat akan menurun sebab naiknya harga-harga

EKSISBANK (Ekonomi Syariah dan Bisnis Perbankan), Volume 5, Nomor 2, Desember 2021 
produk kebutuhan. Peluang ini dapat dimanfaatkan oleh PT. Pegadaian dalam penyaluran pembiayaan Rahn. Karena masyarakat akan memerlukan sumber keuangan sebagai alternatif untuk menambahkan dana simpanan mereka. Namun berdasarkan hasil penelitian, tingkat inflasi tidak berpengaruh secara signifikan terhadap penyaluran pembiayaan rahn yang dilakukan oleh PT. Pegadaian. Hal tersebut bisa jadi disebabkan, pada saat inflasi naik masyarakat lebih memilih opsi mengurangi konsumsi atau menggunakan uangnya untuk sesuatu yang lebih produktif, sehingga hal tersebut tidak berdampak pada kenaikan pembiayaan rahn yang disalurkan oleh PT. Pegadaian Syariah Indonesia. Tingginya tingkat inflasi mengakibatkan semakin meningkatnya suku bunga kredit di sektor perbankan sehingga minat masyarakat untuk meminjam kredit semakin menurun.

Hasil penelitian ini memperkuat hasil penelitian sebelumnya yang dilakukan oleh (Aziz, 2013) karena dalam mengajukan kredit pada PT. Pegadaian masyarakat tidak memperhitungkan berapa besar tingkat inflasi melainkan karena lebih kepada pemenuhan kebutuhan dana yang mendesak. Hasil penelitian ini memperkuat juga hasil penelitian yang dilakukan oleh (Alfarizi \& Riduwan, 2016) menyatakan bahwa tingkat Inflasi tidak berpengaruh secara signifikan terhadap Deposito Mudharabah. Selanjutnya pada hasil penelitian (Suryadi et al., 2020) menunjukkan bahwa inflasi tidak berpengaruh signifikan terhadap profitabilitas (ROA). Dan juga memperkuat hasil penelitian yang dilakukan oleh (Aulia \& Setiawan, 2020) yang menunjukkan bahwa tingkat inflasi tidak berpengaruh terhadap penyaluran pembiayaan gadai rahn yang artinya setiap peningkatan atau penurunan nilai tingkat inflasi tidak akan mempengaruhi besarnya penyaluran gadai rahn. Hal itu dikarenakan produk gadai rahn ini secara mekanismenya terdapat perbedaan dengan produk gadai konvesional yang menggunakan bunga sebagai salah satu dasar pemberian pinjaman.

\section{Pengaruh Pendapatan usaha $\left(\mathbf{X}^{2}\right)$ Pegadaian terhadap pembiyaan Rahn (Y)}

Berdasarkan hasil pengujian regresi menunjukan pendapatan usaha memiliki nilai koefisien yaitu sebesar 0.835 serta nilai $t_{\text {hitung }}$ sebesar 7,141 artinya $t_{\text {hitung }}$ lebih besar dari $t_{\text {tabel }}(7,141>2,365)$ dan nilai signifikan 0,000 $<0,05$. Dari hasil tersebut berarti Ho ditolak pendapatan usaha mempunyai pengaruh positif dan pendapatan usaha berpengaruh secara signifikan terhadap pembiayaan Rahn. Artinya dengan adanya kenaikan atau penurunan pendapatan usaha dapat mempengaruhi perubahan pada pembiayaan rahn. Karena, pendapatan usaha pegadaian merupakan faktor dari internal perusahaan. Sumber dana yang digunakan untuk menyalurkan kredit berasal dari dana pihak ketiga seperti perbankan atau investor lainnya dan dari sisi internal perusahaan diperoleh dari pendapatan sewa modal dan pendapatan administrasi. Sesuai dengan hasil tersebut pendapatan usaha berpengaruh positif terhadap penyaluran pembiayaan rahn pada Pegadaian Syariah di Indonesia. Kenaikan pendapatan usaha pegadaian akan dapat meningkatkan pembiayaan rahn pada pegadaian syariah, Hal ini juga berarti semakin tinggi pendapatan usaha Pegadaian mencerminkan semakin banyaknya kegiatan penyaluran kredit melalui bidang-bidang usaha lainnya yang secara berkesinambungan mencerminkan pergerakan usaha perekonomian masyarakat.

Hasil penelitian ini memperkuat hasil penelitian sebelumnya yang dilakukan oleh (Rubianti, 2017) karena semakin tinggi hasil pendapatan Pegadaian, maka dapat semakin tinggi pula laba yang diperoleh sehingga dapat 
meningkatkan dana untuk penyaluran gadai syariah kepada masyarakat yang mengajukan pembiayaan gadai syariah (Rahn) pada PT Pegadaian. Hasil penelitian ini memperkuat juga hasil penelitian yg dilakukan oleh (Mamulati, 2020) bahwa Pendapatan pegadaian berpengaruh terhadap penyaluran pembiayaan Rahn pada pegadaian syariah. Adanya kenaikan pendapatan pegadaian dapat meningkatkan penyaluran pembiayaan Rahn pada pegadaian syariah. Sebaliknya, penurunan pendapatan pegadaian dapat menurunkan penyaluran pembiayaan Rahn pada pegadaian syariah. Dan juga memperkuat hasil penelitian (Yubiharto et al., 2019) menyatakan bahwa Pendapatan pegadaian memiliki hubungan positif dan signifikan terhadap penyaluran kredit. Artinya semakin tinggi laju pendapatan perum pegadaian yang mencerminkan semakin maraknya kegiatan penyaluran kredit melalui bidang-bidang usaha perum pegadaian yang secara berkelanjutan mencerminkan pergerakan usaha perekonomian bagi masyarakat, yang berdampak pada bertambahanya modal PT.Pegadaian.

\section{E. Pengaruh tingkat inflasi $\left(X^{1}\right)$ dan pendapatan usaha pegadaian $\left(\mathrm{X}^{2}\right)$ terhadap pembiayaan Rahn (Y)}

Berdasarkan hasil pengujian uji simultan (f) diketahui nilai $\mathrm{f}_{\text {tabel }}$ sebesar 4,46 karena nilai $\mathrm{f}_{\text {hitung }} 38.698$ lebih besar dari nilai $\mathrm{f}_{\text {tabel }}$ dan nilai signifikansi sebesar 0,000 jauh lebih kecil dari 0,05. Maka dapat ditarik kesimpulan bahwa secara simultan variabel tingkat inflasi dan pendapatan usaha pegadaian berpengaruh terhadap variabel pembiayaan rahn pada Pegadaian Syariah Indonesia.

Hasil ini memperkuat hasil penelitian sebelumnya yang dilakukan oleh (Desriani \& Rahayu, 2017). Hasil penelitian ini memperkuat juga hasil penelitian yg dilakukan oleh (Mamulati, 2020) yang menyatakan bahwa pegadaian dan harga emas berpengaruh terhadap penyaluran pembiayaan rahn. Artinya pandapatan pegadaian dan harga emas secara bersama-sama. Dan juga memperkuat hasil penelitian (Hariyanti et al., 2019) menunjukan bahwa secara simultan Pendapatan Pegadaian berpengaruh signifikan terhadap penyaluran pembiayaan rahn. Harga emas berpengaruh signifikan terhadap penyaluran pembiayaan rahn. Tingkat inflasi berpengaruh signifikan terhadap penyaluran pembiayaan rahn.

\section{KESIMPULAN}

Berdasarkan dari hasil analisis data dan pemaparan diatas maka dapat disimpulkan bahwa hasil nilai thitung sebesar -0,030, artinya $t_{\text {tabel }}$ lebih besar dari thitung $(2,365>-0,030)$ serta sig.0,977>0,05. Dari hasil tersebut maka Ho diterima secara parsial inflasi mempunyai pengaruh negatif dan inflasi tidak berpengaruh secara signifikan terhadap pembiayaan rahn .

Sedangkan dari hasil nilai thitung pada variabel pendapatan usaha menghasilkan $t_{\text {hitung }}$ sebesar 7,141 artinya thitung lebih besar dari $t_{\text {tabel }}(7,141>2,365)$ serta nilai signifikan $0,000<0,05$. Dari hasil tersebut berarti Ho ditolak secara parsial pendapatan usaha mempunyai pengaruh positif dan pendapatan pegadaian berpengaruh secara signifikan terhadap pembiayaan Rahn.

Hasil pengujian secara simultan (Uji f) pengaruh tingkat inflasi dan pendapatan usaha terhadap pembiayaan Rahn diperoleh hasil nilai $f_{\text {tabel }}$ sebesar 4,46 karena nilai f $f_{\text {hitung }}$ 38.698 lebih besar dari nilai $\mathrm{f}_{\text {tabel }}$ dan nilai signifikansi sebesar 0,000 jauh lebih kecil dari 0,05. Maka dapat ditarik kesimpulan bahwa variabel bebas inflasi dan pendapatan pegadaian (Secara simultan) berpengaruh terhadap variabel pembiayaan rahn pada Pegadaian Syariah Indonesia. 


\section{DAFTAR PUSTAKA}

Alfarizi, F., \& Riduwan, A. (2016). Pengaruh Inflasi, Suku Bunga, Likuiditas, dan Bagi Hasil Terhadap Deposito Mudharabah. Jurnal Ilmu Dan Riset Akuntasi, 5(April), $1-16$.

Almunawwaroh, M., \& Marliana, R. (2018). Pengaruh Car,Npf Dan Fdr Terhadap Profitabilitas Bank Syariah Di Indonesia. Amwaluna: Jurnal Ekonomi Dan Keuangan Syariah, 2(1), 1-17.

Amir, R. (2015). Gadai Tanah Perspektif Ekonomi Islam. Muamalah,Gadai Perspektif Ekonomi Islam Yang, V(1), 81-90.

Aulia, M. I., \& Setiawan, I. (2020). Pengaruh Pendapatan Pegadaian, Tingkat NPL, Tingkat Inflasi dan Harga Emas Tehadap Penyaluran Pembiayaan Gadai Rahn Pada Pegadaian Syariah. Journal of Applied Islamic Economics and Finance, 1(1), 246-257.

Aziz, M. A. (2013). Analisis Pengaruh Tingkat Sewa Modal , Jumlah Nasabah , Harga Emas Dan Tingkat Inflasi Terhadap Penyaluran Kredit Gadai Golongan C ( Studi Pada Pt Pegadaian Cabang Probolinggo ). Jurnal Ilmiah, 1, 21.

Christine, D., Wijaya, J., Chandra, K., Pratiwi, M., Lubis, M. S., \& Nasution, I. A. (2019). Pengaruh Profitabilitas, Leverage, Total Arus Kas dan Ukuran Perusahaan terhadap Financial Distress pada Perusahaan Property dan Real Estate yang Terdapat di Bursa Efek Indonesia Tahun 2014-2017. Jesya (Jurnal Ekonomi \& Ekonomi Syariah), 2(2), 340350.

Desriani, I. P., \& Rahayu, S. (2017). Analilis Pengaruh Pendapatan, Harga Emas, dan Tingkat Inflasi Terhadap Penyaluran
Kredit (Studi Kasus pada PERUM Pegadaian cabang Jombang Tangerang Periode Maret 2009-September 2011). Jurnal Akuntansi Dan Keuangan, 2(2), 147-165.

Hamdani, H., Lianti, L., \& Dasari, F. (2020). Pengaruh Inflasi, Harga Emas Dan Jumlah Nasabah Terhadap Penyaluran Pembiayaan Ar-Rahn Pada Pt Pegadaian Syariah Unit Geudong. Ekonis: Jurnal Ekonomi Dan Bisnis, 22(1).

Hariyanti, B. I., Askandar, N. S., \& Mawardi, M. C. (2019). Pengaruh Pendapatan Pegadaian, Harga Emas, Tingkat Inflasi Terhadap Penyaluran Pembiayaan Rahn (Studi Kasus Pada Pegadaian Syariah Bonder Lombok Tengah). Jurnal Ilmiah Riset Akuntansi, 8(01), 1-15.

Helmalia, A. (2018). Pengaruh e-commerce terhadap peningkatan pendapatan usaha mikro kecil dan menengah di kota padang helmalia. 3.

Janwari, Y. (2015). Fikih lembaga keuangan syariah (A. kamsyach (ed.)). PT Remaja Rosdakarya Offset.

L. Roficoh, M. G. (2018). Aplikasi akad. 3(2). Mamulati, I. (2020). Pengaruh Pendapatan Pegadaian, Dan Harga Emas Terhadap Penyaluran Pembiayaan Rahn. Ejournal KAWASA, 10(1), 1-8.

Mankiw, N. G. (2018). Pengartar Ekonomi Makro Edisi 7. Salemba 4.

Rasmikayati, E., \& Saefudin, B. R. (2018). Analisis Faktor-Faktor Yang Mampu Mendorong Petani Mangga Untuk Meningkatkan Perilaku Agribisnisnya Pada Era Globalisasi. Paradigma Agribisnis, 1(1), 1-13.

Rosa, Y. Del, Husni, E., \& Idwar. (2017). Pengaruh Tingkat Inflasi Dan Pendapatan Pegadaian Terhadap 
Penyaluran Kredit Rahn Pada Pegadaian Syariah Di Indonesia Tahun 2007 - 2015. Menara Ekonomi, III(5), 116-127.

Rosadi, R. A., \& Waluyo, I. (2017). Pengaruh Gender, Tekanan Ketaatan, Tekanan Anggaran Waktu Dan Pengalaman Audit Terhadap Audit Judgment. Nominal, Barometer Riset Akuntansi Dan Manajemen, 6(1), 124-135.

Rubianti, T. (2017). Analisis Pengaruh Jumlah Nasabah, Pendapatan Dan Harga Emas, Teni Rubiyanti. Jurnal Ekonomi Dan Bisnis, 31-55.

Saputri, D. A., \& Dewi, R. K. (2020). Jurnal Bisnis dan Akuntansi Unsurya Pegadaian adalah sebuah BUMN Pendapatan adalah kenaikan kekayaan perusahaan akibat penjualan produk atau jasa dalam rangka menjalankan kegiatan usaha timbul sektor keuangan Indonesia yang bergerak pada tiga lini bisnis. 5(2), 94-110.

Siti Nurlaela, S. A. M. D. (2017). Pengaruh Ukuran Perusahaan, Pertumbuhan Asset, Profitabilitas Dan Pertumbuhan Penjualan Terhadap Struktur Modal Perusahaan Cosmetics and Household Di Bursa Efek Indonesia. Jurnal Akuntansi Dan Pajak, 18(01), 16-30.

Sulaeman, J. M. (2015). Kepastian hukum gadai tanah dalam islam (1st ed.). deepublish.

Suryadi, N., Mayliza, R., \& Ritonga, I. (2020). Pengaruh Inflasi, Biaya Operasional Terhadap Pendapatan Operasional (Bopo), Dan Pangsa Pasar Terhadap Profitabilitas Bank Umum Syariah Di Indonesia Priode 2012-2018. Jurnal Tabarru': Islamic Banking and Finance, 3(1), 1-10.

Wibisono, A., Rofik, M., \& Purwanto, E. (2019). Penerapan Analisis Regresi
Linier Berganda dalam Penyelesaian Skripsi Mahasiswa. Jurnal ABDINUS: Jurnal Pengabdian Nusantara, 3(1), 30.

Yubiharto, Y., Lestari, B., \& others. (2019). Pengaruh Pendapatan, Jumlah Nasabah, Harga Emas Dan Tingkat Inflasi Terhadap Penyaluran Kredit Cepat Aman (Kca) Di Pegadaian Indonesia Tahun 2009-2017. Medikonis, 19(1), 16-30.

Yuniarti, V. S. (2016). Buku ekonomi makro syariah (1st ed.). CV PUSTAKA SEPI.

EKSISBANK (Ekonomi Syariah dan Bisnis Perbankan), Volume 5, Nomor 2, Desember 2021 http://journal.sties-purwakarta.ac.id/index.php/EKSISBANK/ 